\title{
遺伝的アルゴリズムとニューラルネットワークによる 磁界源電流分布推定
}

$\begin{array}{lllll}\text { 正員 岸本 } & \text { 牧 } & \text { (原 } & \text { 研) } \\ \text { 非会員 坂佐井 } & & \text { 警 } & \text { (原 } & \text { 研) } \\ \text { 正員荒 } & \text { 克 } & \text { 之 } & \text { (原 } & \text { 研) }\end{array}$

Estimation of Current Distribution from Magnetic Fields by combination method of Genetic Algorithm and Neural-Network

Maki Kishimoto, Member, Kaoru Sakasai, Non-member, Katuyuki Ara, Member (Japan Atomic Energy Research Institute)

This paper proposes the inverse estimation method of current distribution from magnetic fields by a combination method of genetic algorithm (GA) and neural-network. We regarded the estimation problem of current distribution as an optimum allocation problem of currents and used GA and neural-network to solve this optimum problem. Case stdies with computer simulation showed its effectiveness.

キーワード：磁界逆問題，遺伝的アルゴリズム，ホップフィールド型ニューラルネットワーク初期值問 題, 最適化問題, 多值化

\section{1.はじめに}

磁界計測の重要な目的の一つに，その磁界を生じさ せている信号源の推定がある。特に，生体磁界計測や 金属材料の非破壊検查の分野に招いて，磁界計測から その源である生体内また双金属内の信号源電流分布を 推定する，いわ加る磁界逆問題の計算が重要課題とな つている。例关壮，生体磁界に朽いては，医療診断や 生体機能解明の面から非常に注目されて扝り(1) (2), また非破壞検査仁おいては，金属材料の内部欠宿学検 出する新しい電磁探傷手法として注目されている( ${ }^{(3)}$ 。 しかし，信号源推定という，いか的る磁界計測におけ る逆問題は, 解が一意に定まらない問題として知られ ている。そこでこの逆問題の解決のために, 様々な磁 界逆問题解決法が提案され，研究されている(4) - (6)。

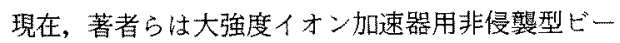
ムモニタの開発を行っており, 完全反磁性シールド板 を用いたイオンビーム断面からの誘導磁界を検出する ことによるビーム電流分布推定法を提案しだ7?。そし
て空間磁界計測データからのビームプロファイルや不 均一電流分布状態の逆推定問題老, 磁界源電流分布領 域への電流最適配置化問題へと㷌着さ甘，この最適化 問題解決の手段として, 遺伝的アルゴリズムを用いた 方法を提案している( ${ }^{(8) \sim(9)}$ 。

遺伝的アルゴリズムは, 生物の遗伝と進化を模擬す るモデルとして考光られた計算理論であり，近年最適 化問題解決の手段として特に注目を集めている(10)。

このアルゴリズムは，遗伝子設計の自由度の高さや

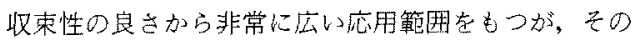
理論的解明が不十分なため, 十分に確立された手法と はなっていない。

一方，遺伝的アルゴリズムと同様に，最適化問题解 決の手法として注目されているものに、ニューラルネ ットワークがある。このニューラルネットワークは， 脳の情報処理を手本にした高度な並列行散情報処理シ ステムであり(11)，最適化問題への応用としては，木 ップフィールド型ニューラルネットワークのネットワ ークエネルギー最小化特性を利用したものが有名であ 
る。しかし，ホップフィールド型ニューラルネットワ ークでは，単調なエネルギー楥和を示すので，ネット ワークの初期状態を適切に設定しないと, 求めたい解 が得られない。ホップフィールド型ニューラルネット ワークを最適化問題に応用する場合には，この初期值 問題を解決する必要がある。

本研究では, 磁界源電流分布逆推定問題を, 電流分 布領域への電流最適配置化問題への㷌着させ，この最 適化問題を解く手段として，ホップフィールド型ニニ ーラルネットワークを適用し，その際問題となるホッ プフィールド型ニューラルネットワークの初期値問題 解決の手段として，遺伝的アルゴリズムを用いた新し い磁界源逆問題解決法を提案した。更に不均一電流分 布の逆推定に対応するために,ニューラルネットワー クと遺伝的アルゴリズムの多值化を行った。そして本 手法の有効性を計算機シミュレーションによって確認 したのでそその結果について報告する。

2. 遺伝的アルゴリズムによるホップフィール ド型ニューラルネットワークの初期值問題 の解決

ホップフィールド型ニューラルネットワークの最適 化問題への応用は, ネットワークエネルギーと求めた い事象とを関連づけることにより，ネットワークを作 動させるとネットワータエネルギーが減少することを 利用して，最適解を求めるものである。しかし，この 手法の問題点は, 得られる解が必ずしも求めたい解で はないことである。すなわち，ホップフィールド型ニ ユーラルネットワークでは, ネットワークの作動に伴 うエネルギ一変化が単調な緩和過程を示すため，ある 任意の初期状態からネットワークを作動させても, 途 中の局所解 (local minimum) にトラップされてしま い，求めたい最適解（global minimum）が必ずしも 得られないのである。ネットワークの初期状態をどの ように設定すれば求めたい最適解が得られるかなど事 前にわからないため, 実際の最適化問題への応用を考 えた場合, この初期值問題を解決する必要があ る(12)。この問題に刘しては, ネットワークエネルギ 一が単調減少ばかりでなく，増加方向へのネットワー ク変化も, ある確率で認めるボルツマンマシン ${ }^{(13)}$ ような手法が提案されている。

本研究ては, この初期問題の解決に, 遺伝的アルゴ リズムのもつ高い検索能力を利用し，ニューラルネッ トワークが最適解に収束するような初期状態を求める ことを考える。すなわち，磁界源電流分布状態を遺伝 的アルゴリズムにおける遗伝子とし，それを幾つか用
意することによって遺伝子集団を形成する。そして， これら遗伝子の一つ一つをニューラルネットワークの 初期状態として与えて，ネットワークを作動させる。 当然ネットワークはある局所解に取束するが，ここで この収束状態の表す電流分布が磁界測定点に作る磁界 と，磁界測定值との誤差を，その遺伝子の評価值とす る。この評価值をもとに，遺伝子集団に対して淘汰ゃ 増殖・交差・突然変異などの遺伝的アルゴリズムの遺 伝子操作を加えることによって、ニューラルネットワ 一クの収束状態の表す電流分布が各測定点に作る磁界 と測定磁界との誤差が最小になるような初期条件を検 索する。そして，このときのネットワータの収束状態 が表す電流分布を, 求める磁界源電流分布とするのて ある。

\section{3. 遺伝的アルゴリズムとニューラルネットワ} 一クの磁界源電流分布逆推定問題への応用

本研究では，平面に垂直に電流が流れる三次元モデ ルを考える。测定体系を図 1 に示す。まず，電流が分 布する二次元平面を細かな微小領域に分割し，この電 流分布領域を流れる電流は，これら微小領域を流れる 電流の和で表されるとする。そして各微小領域を流れ る電流の方向成分は，すべて同一方向加つ二次元平面 に垂直方向のみであるとする。更に，それら微小領域 を流れる電流によって生じる磁界を電流分布領域の周 りに電置した磁界測定点で観湘する。

図 1 で電流分布がある涺定点 $\alpha$ に作る磁界は,

$$
\boldsymbol{B}^{\alpha}=\frac{\mu_{0}}{2 \pi} \sum_{i}^{M} \sum_{j}^{N} \frac{\boldsymbol{I}_{i j} \times\left(\boldsymbol{r}^{\alpha}-\boldsymbol{r}_{i j}\right)}{\left|\boldsymbol{r}^{\alpha}-\boldsymbol{r}_{i j}\right|^{2}}
$$

となる。たたし， $\boldsymbol{r}^{a} ， r_{i j}$ はそれぞれ測定点 $\alpha$ ，微小

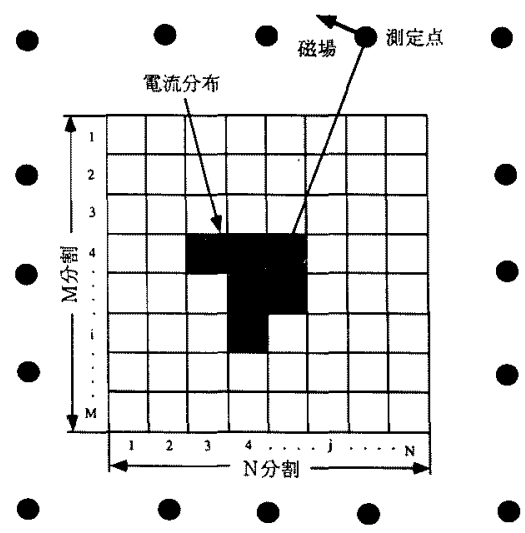

図 1 測定体系

Fig. 1. System of measurement.

T. IEE Japan, Vol. 113-C, No. 9, '93 
領域 $(i, j)$ の位置ベクトル, $\boldsymbol{I}_{i j}$ は微小領域 $(i, j)$ を流 れる電流である。ここで測定点 $\alpha$ における磁界測定 値を $\boldsymbol{B}^{\alpha}{ }_{m}$ とすると, 電流分布領域を取り囲む磁界測 定点での測定值とモデルの電流分布が作る磁界との差 の程度を示す磁界誤差評価開数は

$$
\frac{1}{2} \sum_{\alpha}\left|\boldsymbol{B}_{m}^{\alpha}-\boldsymbol{B}^{\alpha}\right|^{2}
$$

\section{と表される。}

すると, この磁界源電流分布逆推定問題は, 電流分 布領域を分割した微小領域に, ある大きさの電流密度 を，それが作る磁界がすべての測定点で観測された磁 界測定值に一致するように配するという電流最適配置 化問題へと帰着させることができる。しかし，この最 適化問題へ, ニューラルネットワークや遺伝的アルゴ リズムを適用するためには, 磁界源電流分布状態をこ れらの手法で扱えるように定式化することと, 更に分 布する電流が任意の大きさをとることができるため, 遺伝的アルゴリズムやニューラルネットワークを多值 化する必要がある。

\section{4. 電流分布領域における磁界源電流分布状態}

まず，図 1 に示すように，測定対象である電流分布 領域を $M$ 行 $N$ 列のメッシュに分解する。ここである 任意の単位電流密度 $J_{u}$ を仮定し, 各微小領域に 0 か ら 255 までの整数值をそこに流れる電流の大きさとし て与える。すると辺の長さ $\delta_{x}, \delta_{y}$, 位置 $(i, j)$ で表さ れる微小領域を流れる電流 $\boldsymbol{I}_{i j}$ は,

$$
\boldsymbol{I}_{i j}=n_{i j} \boldsymbol{J}_{u} \delta_{x} \delta_{y}
$$

となり,この二次元の磁界源電流分布領域の状態は, 電流密度 $n_{i j}$ を要素とする $M$ 行 $N$ 列の整数行列によ って表すことができる〔図2(a)，（b))。この整数行 列を, 磁界源電流分布状態を表す状態行列として, 二 ューラルネットワークのネットワーク状態や遺伝的ア ルゴリズムの遺伝子として使用する。

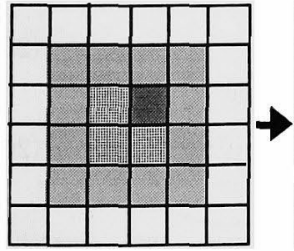

(a) 電流分布

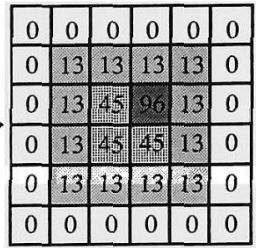

(b) 状態行列
図 2 電流分布状態

Fig. 2. State of current distribution.

\section{5. ニューラルネットワークの多値化}

電流分布が, 状態行列 $\boldsymbol{n}$

$$
\boldsymbol{n}=\left[\begin{array}{cccc}
n_{11} & n_{12} & \cdots & n_{1 N} \\
n_{21} & n_{22} & & \bullet \\
\bullet & & & \bullet \\
n_{M 1} & \bullet & \cdots & n_{M N}
\end{array}\right]
$$

で表されるときのネットワークのエネルギーを，

$$
E(\boldsymbol{n})=-\frac{1}{2} \sum_{i, j} \sum_{k, l} W_{i j, k l} n_{i j} n_{k l}-\sum_{i, j} T_{i j} n_{i j}
$$

$W_{i j, k l}$ ：位置 $(i, j)$ と $(k, l)$ のユニット間の結

合係数, $T_{i j i}$ : 位置 $(i, j)$ のユニットのしき い值

と定義する。ここで求めたい磁界源電流分布は，(2） 式で表される誤差評価関数を最小にするものであるの で, これとネットワークのエネルギー関数式 $(5)$ を結 び付けるためのネットワークの結合係数としきい值を 求めなければならない。また，図 1 の測定体系に二ュ ーラルネットワークを適用した場合, ユニットの出力 が 0 から 255 の整数值をとるため, 多值化された二ュ ーラルネットワークのエネルギー変化と収束について 明らかにしておく必要がある。

〈5・1〉 ニューラルネットワークの結合係数としき い値 $\quad(1)$ 式より, 位置 $\left(a_{a}, b_{a}\right)$ の測定点 $\alpha$ に位置 $\left(x_{i j}, y_{i j}\right)$ の微小領域 $(i, j)$ の電流が作る $\boldsymbol{B}^{\alpha}{ }_{i j}$ は,

$$
\boldsymbol{B}^{\alpha}{ }_{i j}=\left(-\frac{\mu_{0} I_{i j}}{2 \pi} \frac{\left(b_{\alpha}-y_{i j}\right)}{r^{\alpha}{ }^{2}{ }^{2}}, \frac{\mu_{0} I_{i j}}{2 \pi} \frac{\left(a_{a}-x_{i j}\right)}{r^{a}{ }^{2}{ }^{2}}\right)
$$

$$
\text { ただし，（3)式などにより }
$$

$$
\begin{aligned}
& I_{i j}=n_{i j} J_{u} d x d y \\
& r^{\alpha}{ }_{i j}=\sqrt{\left(a_{\alpha}-x_{i j}\right)^{2}+\left(b_{\alpha}-y_{i j}\right)^{2}}
\end{aligned}
$$

である。これより, 測定点 $\alpha$ に電流分布領域の全電 流が作る磁界 $\boldsymbol{B}^{\alpha}$ は,

$$
\begin{aligned}
\boldsymbol{B}^{\alpha}= & {\left[-\frac{\mu_{0} J_{u} \delta x \delta y}{2 \pi} \sum_{i, j} \frac{\left(b_{\alpha}-y_{i j}\right)}{r^{\alpha}{ }_{i j}{ }^{2}} n_{i j},\right.} \\
& \left.\frac{\mu_{0} J_{u} \delta x \delta y}{2 \pi} \sum_{i, j} \frac{\left(a_{\alpha}-x_{i j}\right)}{r^{{ }^{a}}{ }^{2}{ }^{2}} n_{i j}\right] \ldots .
\end{aligned}
$$

と表される。

従って, ( 3 )式の䛠差評価関数は,

$$
\begin{aligned}
\frac{1}{2} \sum_{\alpha}\left|\boldsymbol{B}^{\alpha}{ }_{m}-\boldsymbol{B}^{\alpha}\right|^{2} & \\
= & \frac{1}{2} \sum_{\alpha}\left(\boldsymbol{B}^{\alpha}{ }_{m(x)}-\boldsymbol{B}^{\alpha}{ }_{(x)}\right)^{2} \\
& +\frac{1}{2} \sum_{\alpha}\left(\boldsymbol{B}^{\alpha}{ }_{m(y)}-\boldsymbol{B}^{\alpha}{ }_{(y)}\right)^{2}
\end{aligned}
$$

電学論 C, 113 巻 9 号, 平成 5 年 


$$
\begin{aligned}
& =\left\{\frac{1}{2} \sum_{a} B^{\alpha}{ }_{m(x)}{ }^{2}+\frac{1}{2} \sum_{\alpha} B^{\alpha}{ }_{m(y)}{ }^{2}\right\} \\
& +\sum_{i, j}\left\{\frac{\mu_{0} J_{u} d x d y}{2 \pi} \sum_{\alpha} \boldsymbol{B}^{a}{ }_{m(x)} \frac{\left(b_{\alpha}-y_{i j}\right)}{r^{\alpha}{ }^{2}{ }^{2}}\right. \\
& \left.-\frac{\mu_{0} J_{u} d x d y}{2 \pi} \sum_{\alpha} B^{\alpha}{ }_{m(y)} \frac{\left(a_{\alpha}-x_{i j}\right)}{r^{\alpha}{ }_{i j}^{2}}\right\} n_{i j} \\
& +\frac{1}{2} \sum_{i, j} \sum_{k, l}\left\{\left(\frac{\mu_{0} J_{u} d x d y}{2 \pi}\right)^{2}\right. \\
& \times \sum_{\alpha} \frac{\left(b_{a}-y_{i j}\right)}{r^{a}{ }^{2}{ }^{2}} \frac{\left(b_{\alpha}-y_{k l}\right)}{r^{\alpha}{ }_{k l}{ }^{2}}+\left(\frac{\mu_{0} J_{u} d x d y}{2 \pi \pi}\right)^{2} \\
& \left.\times \sum_{\alpha} \frac{\left(a_{a}-x_{i j}\right)}{r^{\alpha}{ }_{i j}{ }^{2}} \frac{\left(a_{a}-x_{k l}\right)}{r^{\alpha}{ }^{2}{ }^{2}}\right\} n_{i j} n_{k l}
\end{aligned}
$$

となる。

この式で, 第1 項は磁界測定値であり一定であるの で, 誤差評価の議論に関して無視してもかまわない。 そこで(10)式の第 2 項，第 3 項をニューラルネットワ ークのエネルギー式 (5) と比較することにより，ネッ トワークの結合係数としきい值はとれぞれ

$$
\begin{aligned}
& W_{i j, k l}=-\left\{\left(\frac{\mu_{0} J_{u} d x d y}{4 \pi}\right)^{2} \sum_{\alpha} \frac{\left(b_{\alpha}-y_{i j}\right)}{r^{a}{ }^{2}{ }^{2}}\right. \\
& \times \frac{\left(b_{a}-y_{k l}\right)}{r^{a}{ }_{k l}{ }^{2}}+\left(\frac{\mu_{0} J_{u} d x d y}{4 \pi}\right)^{2} \\
& \left.\times \sum_{\alpha} \frac{\left(a_{a}-x_{i j}\right)}{r^{\alpha}{ }_{i, j}^{2}} \frac{\left(a_{a}-x_{k l}\right)}{r^{\alpha}{ }^{2}{ }^{2}}\right\} \\
& T_{i j}=-\left\{\frac{\mu_{0} J_{u} d x d y}{4 \pi} \sum_{\alpha} B^{\alpha}{ }_{m(x)} \frac{\left(b_{a}-y_{i j}\right)}{r^{\alpha}{ }_{i j}^{2}}\right. \\
& \left.-\frac{\mu_{0} J_{u} d x d y}{4 \pi} \sum_{\alpha} \boldsymbol{B}^{\alpha}{ }_{m(y)} \frac{\left(a_{\alpha}-x_{i j}\right)}{r^{\alpha}{ }^{2}{ }^{2}}\right\}
\end{aligned}
$$

となる。

〈5・2〉多値化されたニューラルネットワークの工 ネルギー変化とその収束いま，(5)式のネットワ ークのエネルギー関数に,

$$
W_{i j, k l}=\left(1-\delta_{i j, k l}\right) W_{i j, k l}+\delta_{i j, k l} W_{i j, k l}
$$
ただし，

$$
\delta_{i j, k l}= \begin{cases}1 & (i=k, j=l) \\ 0 & (\text { その他 })\end{cases}
$$

を代入すると，

$$
\begin{aligned}
E(\boldsymbol{n})= & -\frac{1}{2} \sum_{i, j} \sum_{k, l}\left(1-\delta_{i j, k l}\right) W_{i j, k l} n_{i j} n_{k l} \\
& -\frac{1}{2} \sum_{i, j} W_{i j, i j} n_{i j}{ }^{2}-\sum_{i, j} T_{i j} n_{i j} \cdots \cdots
\end{aligned}
$$

となる。ここで， $n_{i j}$ が任意の整数值をとるとすると， 上式は多重一次形式(14) とならず，ホップフィールド ネットワークのように $W_{i, i j}=0$ の条件が成り立たな $\omega_{0}$
そこでまず初めに,ネットワークの作動条件として, ネットワークは非同期で作動するとする。いま位置 $(i, j)$ のニニット状態が $\Delta n$ 変化したとき, 状態変化 前後でのエネルギ一変化量 $\Delta E$ は，ネットワークが 非同期で作動することから，

$$
\begin{aligned}
\Delta E= & -\frac{1}{2} \sum_{i, j}\left(W_{i j, k l}+W_{k l, i j}\right) n_{k l} \Delta n \\
& -\frac{1}{2}\left\{W_{i j, i j}\left(n_{i j}+\Delta n\right)^{2}-W_{i j, i j} n_{i j}\right\}^{2} \\
& -T_{i j} \Delta n \ldots \ldots \ldots \ldots \ldots \ldots \ldots \ldots \ldots \ldots \ldots \ldots \ldots \ldots \ldots \ldots \ldots \ldots \ldots
\end{aligned}
$$

ここで, (11)式より, $W_{i j, k l}=W_{k l, i j}$ なので

$$
\Delta E=-\Delta n U_{i j}-\frac{1}{2}\left(\Delta n^{2}+2 \Delta n n_{i j}\right) W_{i j, i j}
$$

$$
\begin{aligned}
& \text { ただし, } U_{i j} \text { は } \\
& U_{i j}=\sum_{k, l(\neq i, j)} W_{i j, k l} n_{k l}+T_{i j}
\end{aligned}
$$

であり，ホップフィールドネットワークに出てくるュ ニットへの入力信号の総和にあたる。

ここで，エネルギー変化 $\Delta E$ が 0 以下となるよう な $\Delta n$ の変化条件は, (17)式より

$$
-\Delta n U_{i j}-\frac{1}{2}\left(\Delta n^{2}+2 \Delta n n_{i j}\right) W_{i j, i j} \leq 0 \cdots
$$

(11)式より $W_{i j, i j}$ は常に $W_{i j, i j} \leq 0$ なので,

$$
\left\{\Delta n+2\left(n_{i j}+\frac{U_{i j}}{W_{i, i j}}\right)\right\} \Delta n \leq 0
$$

ここで,

$$
\gamma=n_{i j}+\frac{U_{i j}}{W_{i j, i j}}
$$

とすると， $\Delta E \leq 0$ となる $\Delta n$ の条件は，

(1) $\gamma \geq 0$ のき

$$
-2 \gamma \leq \Delta n \leq 0
$$

(2) $\gamma<0$ のき

$$
0 \leq \Delta n \leq-2 \gamma
$$

次に，エネルギーが変化しなくなる条件は， $\Delta n$ が 整数であることを考慮すると，

(1) $\gamma \geq 0$ のとき

$$
-1<-2 \gamma \leq \Delta n \leq 0
$$

(2) $\gamma<0$ のき

$$
0 \leq \Delta n \leq-2 \gamma<1
$$

この 2 式をまとめると，結局

$$
-\frac{1}{2}<\gamma<\frac{1}{2}
$$

となる。

このニューラルネットワークは，(22)，(23)式で表 される条件で $n_{i j}$ を変化させると, 単純なエネルギー 緩和過程を示し, 最終的に各ユニットの状態が (26) 式 
$\mathrm{GA}$ とニューロによる電流分布推定

で表されるようなある任意の状態に収束することがわ かる。ただし，本研究のニューラルネットワークで は， $n_{i j}$ は 0 から 255 まてという制限があるので，ネ ットワークの収束点で必ずしもすべてのニニットが (26)式を満たしているわけではない。

\section{6. 遺伝的アルゴリズム}

〈6.1〉遺伝子と遺伝子集団本研究に㧈讪る遗 伝的アルゴリズムの役割は, ニューラルネットワーク が最適解に収束するような初期状態を見つけることで ある。従って，電流分布を表す状態行列を遺伝的アル ゴリズム処理における遺伝子とし，これを幾つ汃用意 して遺伝子集団を形成させる(図 3 )。この遺伝子集 団に対して, 次に示すような遺伝的アルゴりズムの遺 伝子操作を行う。

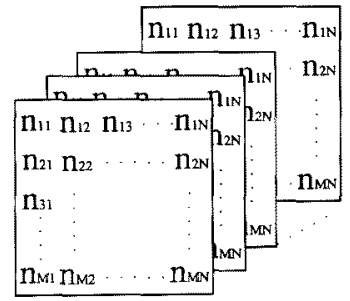

図 3 遗伝子集団

Fig. 3. Population.

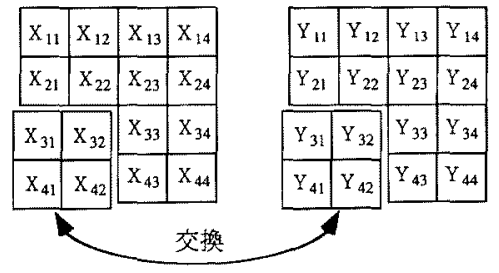

図 4 交差

Fig. 4. Cross-over.

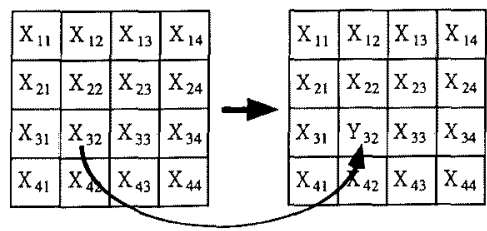

図 5 突然変暴

Fig. 5. Mutation.
〈6・2〉遗伝子操作 本研究での遺伝的アルゴリ ズムは，(1）淘汰おょび增殖，(2) 交差，(3) 突然変異の三つの遺伝子操作からなる。

（1）淘汰㧍上び增殖遺伝子をニューラルネッ トワークの初期值として作動させたときの収束状態が 表す電流分布の磁界哭差を，（2）式の磁界誤差評価関 数で評価し，評価の悪い遺伝子を一定割合で削除する ことにより，淘汰を行う。次に淘汰によって減少した 分を評価の高い遺伝子を複写して補うことによって增 殖とする。

（2）交差 遺伝子集団の中から，ランダムに任 意の二つの遺伝子を選択し，并の一部行を交換する二 次元交差を行引(図 4)。交換する領域の大ききや位監 も乱数老用いて決定する。

（3）突然変異 遺伝子集団の中から任意の一つ を選び出し，その一部を乱数を用いて値を変化させる (図 5 )。

以上の(1)〜(3)までの処理を一世代として，これ を繰り返すことにより，第 2 章で示したようにニュ ーラルネットワークの収束結果の表す電流分布の磁界 誤差評価值が，最小になるようなネットワーク初期状 態を求めていく。

7. ニューラルネットワークと遺伝的アルゴ リズムによる磁界源電流分布逆推定法

図 6 に、ニューラルネットワータと遺伝的アルゴリ ズムに上る磁界源電流分布推定法の流れ図を示す。ま ず, 電流密度の大きさを要素とする状態行列を遗伝子 とし，その遺伝子集団を任意に初期化し，各遺伝子を ニューラルネットワークの初期状態として与えて, ネ ットワークを作動させる。すると遗伝子は, それぞれ 初期状態に対応したある局所解に取束する。その収束 点での磁界誤差評洒值をその遺伝子の評值値であると して，第6 朝で示したような遺伝的アルゴリズムの交 差や突然変異などの遗伝子操作を行うことによって， 新たなニューラルネットワークの初期值集団を決定す る。そしてまたニューラルネットワークを作動さ せ,ネットワークの収束状態で磁界誤差評価を行う。 以上の手続きを何度も繰り返すことにより，最終的 に，ネットワークがもつとも良い取束結果，すなわち (2)式で表される磁界譟荎評洒関数が最小となるよう な, 電流分布に収束する初期状態を遺伝的アルゴリズ ムによって検索するとともに，てのときのニューラル ネットワークの収束結果が表す電流分布を，求める磁 界源電流分布とする。 


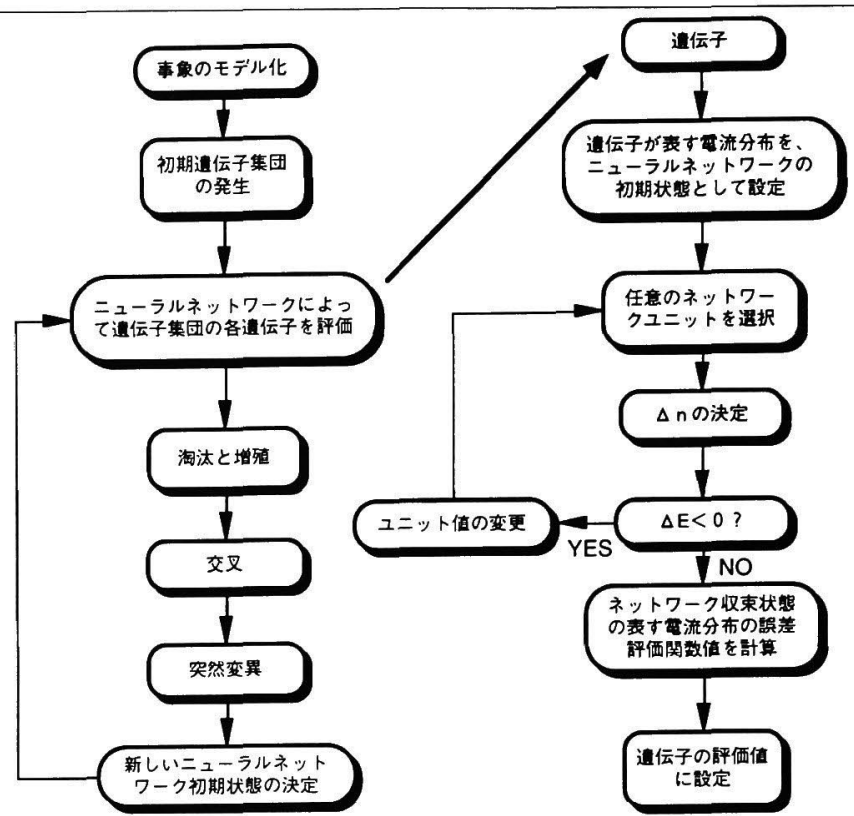

図 6 ニューラルネットワークとGAによる磁界源電流分布逆推定法流れ図

Fig. 6. Flow diagram of estimation method of current distribution by neural network and GA.

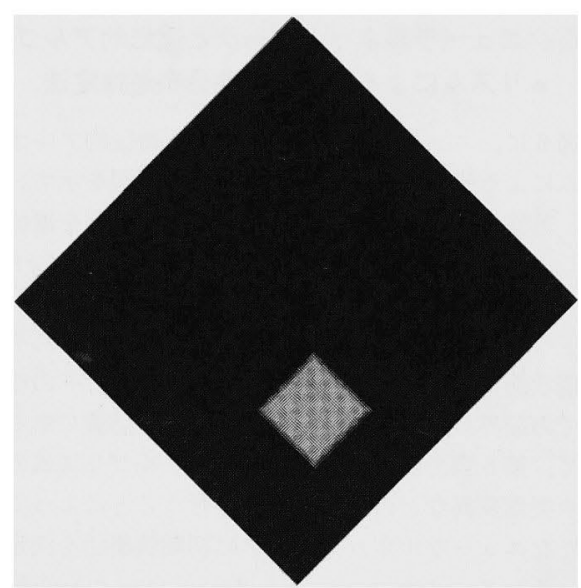

図 7 求める電流分布

Fig. 7. Real current.

8. シミュレーションによる検証

シミュレーション方法は, まず初めに求めたい電流 分布を設定し, それが各測定点に作る磁界計算値を磁 界測定值とする。本研究のシミュレーションで電流分 布逆推定に用いるのは, 測定点におけるこれら空間磁 界データのみで, 測定領域内で電流が幾つに分離して 存在しているか, 測定領域内に流れる全電流值や電流

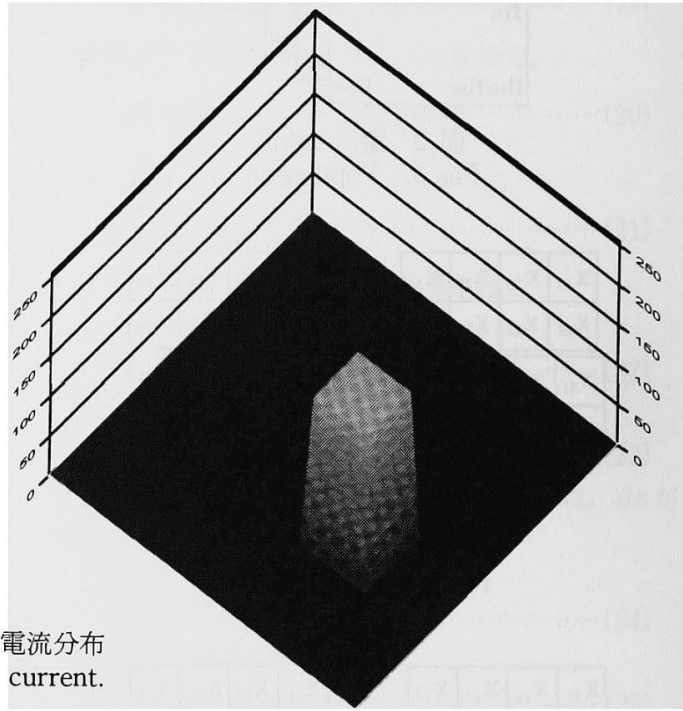

表 1 計算パラメータ

Table 1. Parameters of the simulation.

\begin{tabular}{c|c}
\hline 測定領域の分割数 & $256(16 \times 16)$ \\
\hline 測定点数 & 24,32 点 \\
\hline 測定点配置 & ランダム配置 \\
\hline 電流分布微小領域数 & 10 領域 \\
\hline 遺伝子集団数 & 100 個 \\
\hline
\end{tabular}




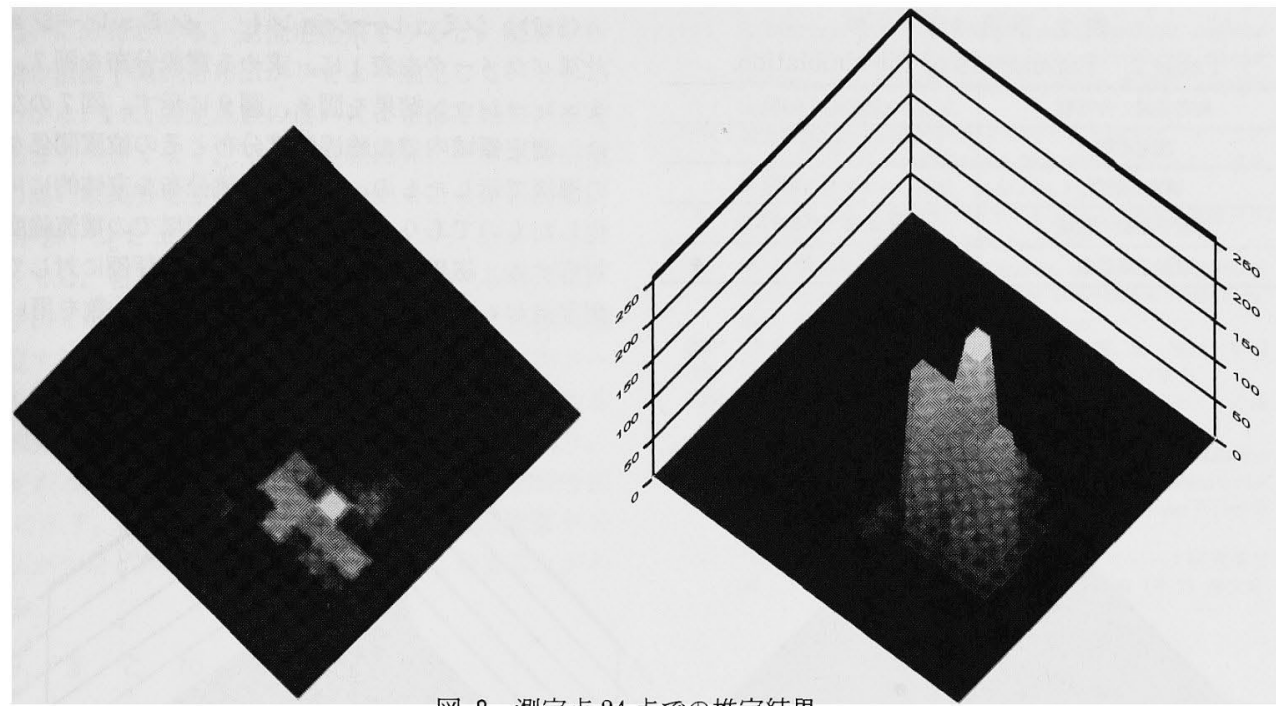

図 8 測定点 24 点での推定結果

Fig. 8. Estimation result (24 measureing points).
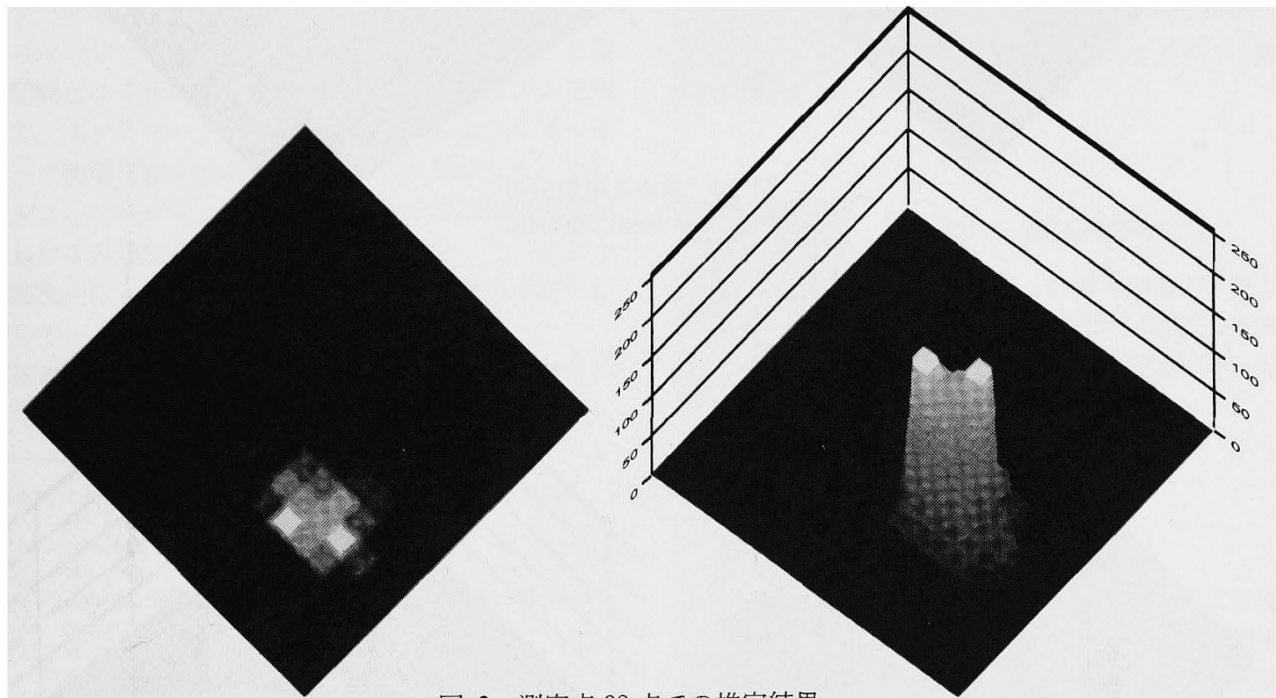

図 9 測定点 32 点での推定結果

Fig. 9. Estimation result (32 measuring points).

が流れている微小領域数は幾つか, などいつさいわか らないものとする。そして，この磁界データをもとに して, 第 7 章で述べた手法で電流分布の逆推定を行 う。そして計算が進むとともに, 最終的にネットワー クの収束状態での磁界誤差評価値が，ほとんど変化し
ない平衡状態に達するので，このときのネットワーク の収束結果を, 求める逆推定電流分布として計算を終 了する。そしてこの逆推定結果が, 初めに求めたい電 流分布として設定したものと一致するかどうかで，本 手法の有効性の検証を行う。 
表 2 計算パラメータ

Table 2. Parameters of the simulation.

\begin{tabular}{c|c}
\hline 湘定領域の分割数 & $256(16 \times 16)$ \\
\hline 測定点数 & 32 点 \\
\hline 測定点配置 & ランダム配置 \\
\hline 電流分布微小領域 & 18 領域 $(9$ 領域 $\times 2)$ \\
\hline 遺伝子果団数 & 100 個 \\
\hline
\end{tabular}

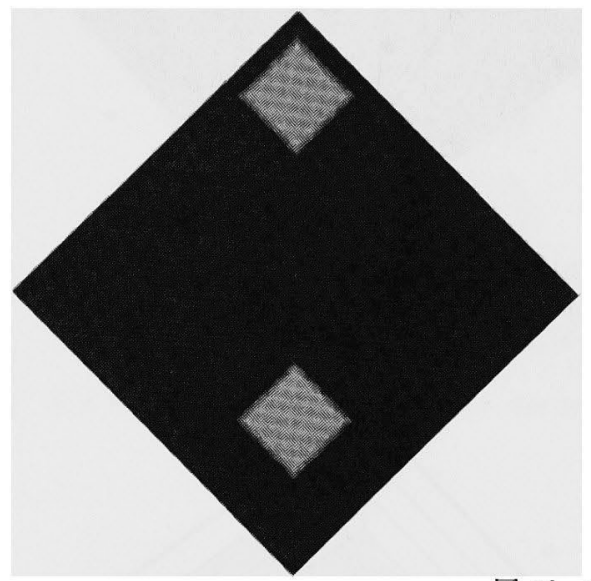

図 10 求める電流分布

Fig. 10. Real current.
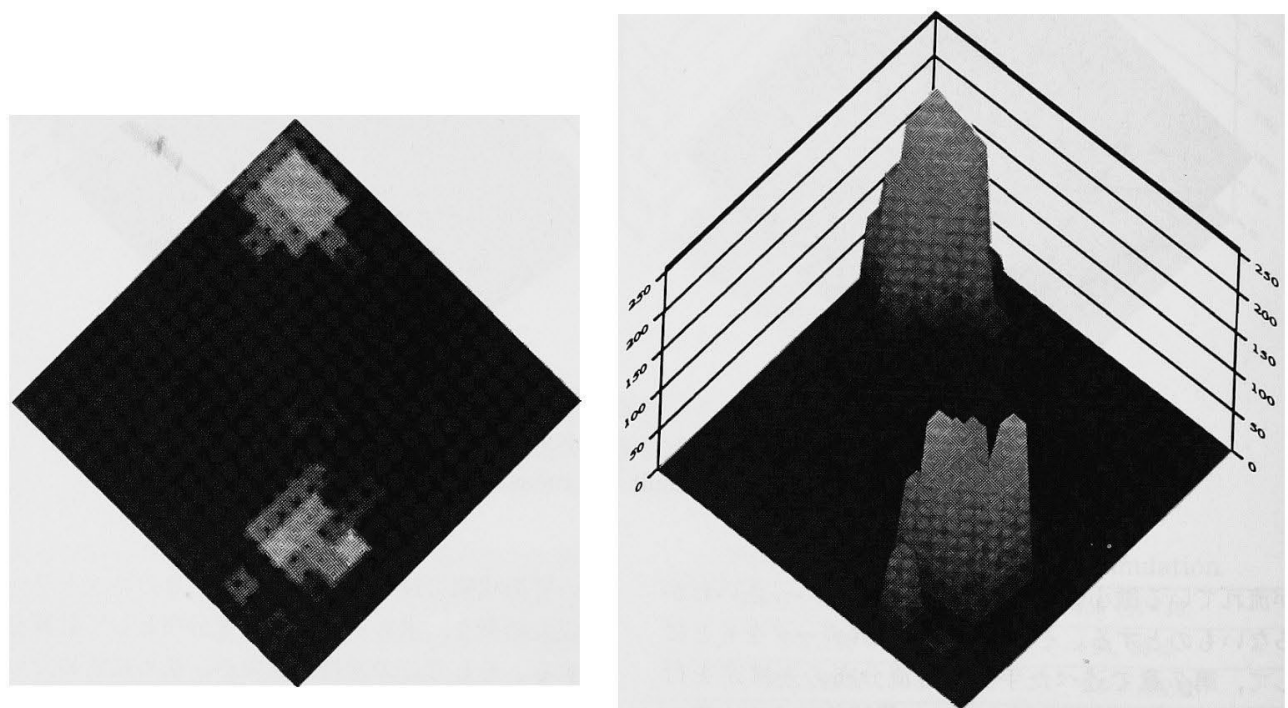

図 11 測定点数 32 点での推定結果

Fig. 11. Estimation result (32 measuring points). 
$\mathrm{GA}$ とニューロによる電流分布推定

不均一に分布させる。逆推定結果をみると, 電流分布 領域の位置や電流分布広がりをよく推定していること がわかる。また, 測定点数の違いによる推定結果の影響 もあまり大きくなく, 少ない空間磁界データでも信頼 度の高い電流分布逆推定が可能であることがわかる。

〈8・2〉 シミュレーション 2 このシミュレーシ ヨンでは, 電流が二つの別れて分布している場合に, 本手法で電流分布の位置や電流分布広がりを正確に逆 推定することができるかの検証を行う。計算パラメー 夕を表 2 に, 求める電流分布を図 10 に示す。求める 電流分布は測定領域内で大きく二つに分離しており, 測定点の位置はランダム配置とする。逆推定結果を図 11 に示す。計算結果をみると, 電流分布の位置や分 布広がりなど非常によく分離逆推定していることがわ かる。

\section{9. ま と め}

本論文では，磁界源電流分布推定を空間的な電流分 布最適配置化問題と考え, この最適化問題解決方法と して, 多值化したホップフィールド型ニューラルネッ トワークを適用した。そして, このホップフィールド 型ニューラルネットワークを最適化問題に適用する際 に問題となる初期值問題を, 遺伝的アルゴリズムを用 いて,ネットワークが最適解に収束するようなネット ワーク初期状態を検索することにより解決した。そし てシミュレーション計算により, 本手法の磁界逆問題 における有効性を示した。今後の課題として，モデル の三次元化と, 更に複雑な不均一電流分布の推定を目 指していく。

(平成 5 年 3 月 17 日受付, 同 5 年 6 月 15 日再受付)

\section{文献}

（1）上野照剛:「磁気の生体効果」, 応用磁気学誌, 15, No.14, 745 (平 3 )

（2）内川義則・古谷 誠:「生体磁気計則」, 同上, 15, No.4, 759 (平 3 )

（3）山田尚生, 他 : 巨次元立方体中の電流分布測定」, 電気学会 マグネティクス研資，MAG-92-135（平 4)

（4）早乙女英夫, 他:「Sampled Pattern Matching 法による生 体内電流分布推定」, 電学論 C, 113, 69 (平 5-1)

（5）鶴岡 久，他：「ニューラルネットワークによる脳磁場信号 源の推定」, 生体磁気学誌, 5, No.1, A 2-6 (平 4-6)
(6) A. Ishiguro, et al.: "A Study Genetic Algoritms' Application to Inverse Problems in Electromagnetics", Nonlinear Phenomena in Electromagnetic Fields (1992) Elsevier Science Publishers B. V.

（7）坂佐井蕌，他：「反磁性平行シールド板と磁界センサによる イオンビームライン断面からの誘導磁界センシング, 電気 学会マグネティクス研資, MAG-90-177 (平2)

（8）岸本 牧, 他：「遺伝的アルコリスムによる磁束源電流分布 の逆推定」, 同上, MAG-92-235 (平 4)

(9) M. Kishimoto, et al : "Application of Genetic Algorithm to Inverse Estimation of Current Distribution from Mag. netic Fields", W-42 ISEM'93-Sapporo

（10）「特集 遺伝的アルゴリズム」，計測と制御，32，No.1 (平 5)

(11) 「特集 ニューラルネット」, 同上, 30, No.4 (平 3)

（12）和田健之介：「GAってなに？一逃伝的アルゴリスムの基 䃈一」, 電学誌, 112 (平 4-10)

(13) E. Aarts \& J. Kort: Simulated Annealing and Boltzmann Machine: A Stochastic Approach to Combinatorial Optimization and Neural Computing. (1989) John Wiley \& Sons

（14）（社）日本工業技術振興協会ニューロコンピュー夕研究部会 編：ニューロコンピューティングの基礎理論（平 2）海文堂

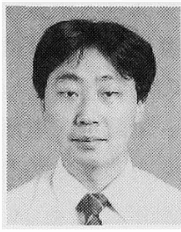

\section{岸本牧（正員）}

昭和 38 年生。6 4 年東京大学大学院修 士課程修了。同年日本原子力研究所入 所。現在, 先端基礎研究センター・量子 計測研究グループ。

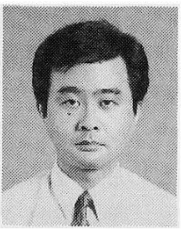

\section{坂佐井}

慗（非会員）

昭和 35 年生。 58 年早稲田大学理工学 部物理学科卒業。同年日本原子力研究所 入所。現在, 先端基礎研究センター・量 子計測研究グループ。

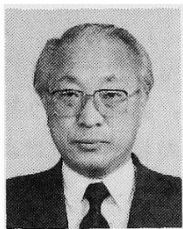

\section{荒克之(正員)}

昭和 14 年生。36 年東京電機大学通信 工学科卒業。現在, 日本原子力研究所入 所主任研究員。センシング技術研究室室 長。工学博士。 